\title{
Article \\ The Communion of the Apostles and the Spiritual Eucharist in the Religious Thought and Art of the Old Believers
}

\author{
Aleksandra Sulikowska-Bełczowska (D) \\ Institute of Art History, University of Warsaw, 00-838 Warszawa, Poland; a.sulikowska@uw.edu.pl
}

check for updates

Citation: Sulikowska-Bełczowska, Aleksandra. 2022. The Communion of the Apostles and the Spiritual Eucharist in the Religious Thought and Art of the Old Believers.

Religions 13: 50. https://doi.org/ $10.3390 /$ rel13010050

Academic Editor: John Jillions

Received: 6 December 2021

Accepted: 30 December 2021

Published: 5 January 2022

Publisher's Note: MDPI stays neutral with regard to jurisdictional claims in published maps and institutional affiliations.

Copyright: (C) 2022 by the author. Licensee MDPI, Basel, Switzerland. This article is an open access article distributed under the terms and conditions of the Creative Commons Attribution (CC BY) license (https:/ / creativecommons.org/licenses/by/ $4.0 /)$.

\begin{abstract}
The division that occurred in the Patriarchate of Muscovy in the middle of the 17th century resulted in a large part of the believers being alienated from the clergy; in consequence, many communities of the Old Believers, who had come to terms with this loss, renounced most of the sacraments, including the Eucharist. This situation impacted the art of the Old Believers, especially in the Priestless Old Believer communities, for instance, in the interiors of their houses of prayer, where the presbytery area disappeared, and the iconostasis changed its function. This article contains an analysis of how one of the old iconographic themes connected with the Eucharist, namely the Communion of the Apostles, functioned in the Old Believer setting. Sources originating from those circles, especially the 18th-century Pomorian Answers (Pomorskie otvety), indicate that the Old Believers saw the Eucharist as a spiritual experience-the only one that was available to the faithful who lived in communities that lacked a clergy. This is most probably the context in which, for instance, Old Believer versions of the Communion of the Apostles should be understood. The view of the Old Believer identity, and Old Believer art, as proposed in this article takes under consideration not only the tradition but also the change, which was an unavoidable part of their communities' experience, and which may also constitute an essential key to our reading of the contents and meaning of Old Believer icons.
\end{abstract}

Keywords: icons; old believers; priestless old believers; communion of the apostles; eastern christian liturgy

\section{Introduction}

The main aim of the existence of all Old Believer communities was the preservation of the Rus' old religion. The believers perceived this religion as identical with the rituals, customs and symbols that were inherited from the past or were simply identified with the past. A concept that the Old Believer milieus saw as central, and mentioned in all the sources it generated, was tradition. The core of the disagreement between the official Orthodox Church and the opponents of the reforms was the symbolic meanings embedded in the rituals: the various details of their interpretation and understanding. The aim of this article is to consider the role that the icons most closely connected with the liturgy played in the Old Believer communities, and consequently, how the Old Believer convictions regarding the liturgy affected the iconography. In the general scholarly perception, the Old Believers retained the principles of the art of Old Rus' until the present times and are the only ones to have resisted the destruction of those principles caused by the occidentalisation of the official Orthodox Church (cf. Tarasov 2002, pp. 327-43). In this article, I make use of Old Believer sources in an attempt to shed new light on the interpretative possibilities offered by the liturgical representations functioning in the "old faith" milieus. To this aim, I shall consider the convictions regarding the liturgy and the Eucharist as indicated by written sources, and I shall compare those with works of art referencing the same issues, especially the representations of the Communion of the Apostles. Further on, I shall reflect on the issue of change as an aspect of the Old Believer experience, considering that they 
fundamentally rejected the very idea of modernisation, but in reality, they were forced to yield to it (cf. Crummey 2011).

\section{Deprived of the Eucharist}

According to all testimonies dating from the middle of the 17th century, the original impulse for the split in the Orthodox Church of Moscow was the changes not only in the liturgical books, but also in ritual practices, starting from as early as 1653 (Meyendorff 1991, pp. 39, 127-31; Sazonova 2008, pp. 52-68). It was not the first time in the history of Eastern Christianity that the issues of liturgy came to lay at the centre of an ideological conflict; however, this time they were understood in a special manner. In contrast to the earlier conflicts between the East and the West, the debate on the Eucharist did not focus on the fundamental issues such as, for instance, its reception under both kinds; this time, the core issue was the very fact of introducing revisions into the contents of liturgical books, as well as the fact that Nikon's reform permitted placing the sign of the Greek cross, instead of the hitherto canonical eight-armed cross, on the liturgical loaf of bread (prosphora) and introduced a new way of dividing the eucharistic bread during the Liturgy of Preparation (proskomedia): into five parts instead of the earlier seven (Chernyavskiy 1860, pp. 5-192; Meyendorff 1991, pp. 138, 148-49) [Figures 4 and 5]. Very quickly, however, another problem developed within the Old Believer communities, a problem that came to dominate this group's attitude to liturgical issues. Namely, it was the shortage, and soon the absence, of clergymen who held on to the old rituals. Apart from their rejection by the state system and repressions by the authorities, this was the greatest price the Old Believers had to pay for preserving the old tradition (Crummey 2011, p. 126).

The absence of clergymen, and consequently the lack of the Eucharist, did not result from the communities' conscious choice but from the fact that after Nikon's reform there was no-one who could consecrate new priests in the "old rite". Only one bishop, Paul of Kolomna, refused to heed reform; he too was soon (in 1656) burnt at the stake, thus becoming an Old Believer martyr (Otvety Aleksandra Diakona 1906, p. 277; cf. Lobachev 2003, pp. 176-77; Crummey 1970, pp. 29-30). By the last years of the 17th century and the very beginning of the 18th century, there had been practically no clergymen left that would have held on to the "old faith". Even before the middle of the 17th century, a venerable elder by the name of Kapiton allegedly refused to receive the Eucharist or blessings from the hands of "unclean" priests or to acknowledge the "new" icons painted under the Western influence, thus becoming the originator of a movement that rejected the clergy in general (Zenkovskiy 1995, pp. 149-50; Lobachev 2003, pp. 36-37; cf. Crummey 2011, pp. 52-67). This attitude found enthusiasts among the opponents of the reforms. The view that a church where Nikonite clergymen served should not be attended began to be accepted. The radicals professed that the believers did not need such priests; it was better that they prayed by themselves (Crummey 1970, p. 23). After the 1666-1667 council, which removed Nikon from office but also pronounced the Old Believers to be schismatics (raskolniki), thus pushing them out of the structures of the Orthodox Church, the Old Believers began to commonly share the view that the Antichrist had come to rule the entire world, whereas the "divine grace" had abandoned it and ascended to heaven. According to many, it was improper to administer the sacraments in this world (Smirnov 1895, p. 95; Zenkovskiy 1995, p. 341).

From there, a straight path led to the formation of Priestless Old Believer (bespopovtsy) communities. In the early 1670s, state reports informed that in the area of Nizhny Novgorod the "simple people" did not attend church, did not participate in the liturgy and that many of them, often whole families, elected to commit suicide by self-immolation (DRB 1791, p. 92). According to Deacon Feodor, who lived in the 17th century and belonged to the first generation of Old Believers, the true Gospel was to live "until the ending of the ages" among the refugees, who hid themselves in remote hermitages and shelters, severing their ties with the world until its end (Subbotin 1881, p. 270). Deacon Feodor lamented the fact that the believers had been deprived of clergymen, laying the blame for this fact on 
Nikon; it was him that caused the believers to live without true shepherds. The latter could work only in hiding (Subbotin 1881, pp. 294-95). Suppressor of the Solovetsky uprising, voivode Ivan Meshcherinov's letter to Tsar Alexei Mikhailovich, written during the siege of the Solovetsky Monastery in 1674, originates from the power circles; it reports the nonparticipation in the liturgy among the followers of the "old faith" (which fact is perceived, significantly, as a condemnation and a proof of their culpability) and contains the charge of homosexuality (Subbotin 1878, p. 328, cf. p. 336), which was a traditional accusation against political opponents, generally used even in Rus'. By the end of the 17th century, in some groups of Priestless Old Believers, namely the Pomortsy and the Fedoseevtsy, only two sacraments had remained: the baptism and the penance, which could be administered by laymen (Mal'tsev 2006, p. 27, cf. p. 34; Smirnov 1895, p. 95). This situation is confirmed as existing in the early 18th century by one of the most important spiritual fathers of Priestless Old Believers, Andrei Denisov, who wrote that after the schism in the Church the believers refused to receive any sacraments from the hands of clergymen belonging to the official Orthodox Church (Denisov, Vtoroe poslanye v Polshu in Smirnov 1909, p. 040; cf. Mal'tsev 2006, p. 35).

However, not all Old Believers were this radical; some of them could not imagine functioning without the clergy (White 2020, p. 32). Especially marriage, which could not be instituted without the presence of a clergyman, constituted a serious problem to the communities (Mal'tsev 2006, pp. 31-36; White 2020, pp. 59, 60). A perusal of Old Believer writings seems to indicate that many regarded this issue as more important than the Eucharist itself (Mal'tsev 2006, pp. 36-37). It certainly was one of the key reasons why, by the end of the 17th century, the Old Believers had already begun to acquire clergymen from the official Orthodox Church. This process resulted in the emergence of the priestly (popoztsy) faction. In order to legitimise the movement, its founders referred to the writings of the "founding fathers", such as Archpriest Avvakum, who maintained that the believers could turn to those clergymen who had been consecrated in the post-Nikonite Church but who abandoned it in order to follow the "old rite" (Smirnov 1898, p. 138). From the late 17th century onwards, the split between the Old Believer denominations depending on their possession of priests-that is, between the priestly and the priestless-was becoming increasingly clearer (Zenkovskiy 1995, p. 343); in the matters of culture, especially the visual arts, it became particularly evident in the 19th century. The situation was complicated by the fact that further splits occurred within both denominations-although within the Priestless Old Believers to a larger extent—and these splits made the movement increasingly heterogeneous, and in many cases actively contentious, regarding practically all the issues, since every group considered its own version of the "old faith" to be the only correct one (Mal'tsev 2006, pp. 23, 27). Hence, the Old Believers remained in a state of constant religious debate not only with the Nikonites but also among themselves, and occasionally their discussions turned so heated that the term "heretics" was bandied-even when the differences between the communities were not very significant. Additionally, a repetition of the baptism was demanded when a person was being accepted into a community, and that was not only when this person was a converted Nikonite, but also an Old Believer formerly belonging to a non-accepted group. Moreover, in some priestless communities it was recommended to deny reverence to icons and crosses created not only in the Nikonite but also in the priestly environment and even to those originating from other priestless groups (Mal'tsev 2006, p. 178; Tarasov 1997, pp. 149-50, 154).

Yet, the most important consequence of the absence of the clergy and the resultant reduction of the liturgy was certainly the fact that those Priestless Old Believers who renounced the Liturgy of the Faithful, that is, the eucharistic liturgy, ceased to divide the space of their church, or more correctly their house of prayer (molenna), into two parts-one reserved for the clergy, the other for the congregation. As a result, the need to have an altar partition disappeared as well, and the name "iconostasis" began to be applied to rows of icons standing by the eastern wall of the chamber (Kozhurin 2014, p. 343; cf. Pivovarova 2017, pp. 173-86). The ordering of the icons was often loose, only partially 
conforming to the Orthodox canon; this often resulted from the fact that the migratory and repressed communities did not have the correct number of icons or lacked icons showing appropriate scenes. Even this example demonstrates how this extremely conservative group of believers-men and women who saw their attitude to tradition as the main marker of their identity-introduced considerable changes when faced with the necessity: changes as significant as the reduction of liturgical rituals, on the one hand, and the transformation of the canonical organisation of the church space on the other. Among other changes resulting from the prohibitions placed on the Old Believers in imperial Russia was the fact that, in order to look like ordinary houses, their houses of prayer were deprived of cupolas, bells and suchlike elements (Kozhurin 2014, pp. 343-44; Robson 1995, pp. 54-55).

Many of the Old Believer icons refer to liturgical issues. Among them are icons that constitute a narrative reference to the events of the Holy Week, for instance the Maundy Thursday, such as the Washing of the Apostles' Feet (Nev'yanskaya ikona 1997, Figure 107). Icons referring to another theme, the Last Supper, come from the priestly milieu of Vetka and the priestless - of Lithuania (Paaver and Potashenko 2016, Figures 57 and 73; Potashenko 2017, Figure 2) and Yaroslavl (Pivovarova 2017, p. 90). The theme is mentioned in the catalogues of icons originating from Old Believer communities; yet, unfortunately, in the case of such texts, it is usually impossible to confirm the iconography (Pivovarova 2004, p. 375, no. 124), even though it is known that, for instance, the household house of prayer of the merchant Nikolai Papulin contained an icon showing "the Last Supper, when the Saviour offers a cup to the apostles" (Pivovarova 2004, p. 376, no. 143). Similar representations are also frequently found in multiple-scene icons (Grebenyuk 2004, p. 287), especially those showing the Passion cycle. Apart from narrative themes, icons produced in various Old Believer groups quite often represent the image of Christ the Archpriest, known as the Tsar of Tsars (Gorbunov and Khersonskiy 2000, p. 57, Figure 19; Nechaeva 2002 , p. 25). However, liturgical themes were most often represented in an indirect manner, for instance through the very popular image of Saint John the Baptist the Angel of the Desert with a chalice (poteiron) in his hand; the chalice contains the recumbent figure of naked, youthful Christ, which in this context certainly refers to the Eucharist (Nechaeva 2002, pp. 38, 75; Nev'yanskaya ikona 1997, Figure 144; Pivovarova 2017, pp. 30, 165; Sulikowska 2013, pp. 205-8). Another relatively similar image is the figure of Christ behind the altar in the icons of Archangel Michael the Arch-Strategist of the Heavenly Hosts, which were also common among the Old Believers (Nechaeva 2002, pp. 155-61; Pivovarova 2017, pp. 19, 140). Icons of the Old Testament Holy Trinity, showing three angels seated behind an altar table during a heavenly feast, had a similar context as in the art of Old Rus' (Kobrzeniecka-Sikorska 1993, cat. no. 64; Nechaeva 2002, pp. 189-91).

Among all the above representations, the most widespread was certainly the iconography of the Old Testament Holy Trinity. It is worth noting that most of these themes are found also in metal casts, which in private devotion fulfilled the same role as icons and were very popular among the Old Believers (Karpenko 2006, pp. 45, 48-49). In addition, the Old Believer milieu produced very large numbers of didactic and polemical prints showing the difference between the old and the new rite. Those prints illustrate the differences in church interiors, priests' vestments, shapes of the cross, signs on the eucharistic bread and the manner of dividing it. Thus, they refer to the issues that arose directly from Nikon's reform as well as to the issues that were a later consequence of the occidental orientation evinced by the official Orthodox Church and then the reforms introduced in the reign of Peter I and after it (Itkina 1992, pp. 57-60, cat. no. 5-6, 61, 103) (Figures 4 and 5).

\section{The Communion of the Apostles}

The Communion of the Apostles is a topic which until now had not been discussed in scholarly literature in the context of the Old Believers, even though representations of the Communion of the Apostles seem to be the most interesting and at the same time the least frequently encountered among the liturgical icons present in the Old Believer milieu. One of those is a large icon, most probably dating from the 19th century, held 
by the National Museum in Warsaw $(53 \times 73.5 \mathrm{~cm}$, inv. no. IK 79 NMW) (Figure 1). Its provenance is unknown, but all of its features point to its connection with an Old Believer circle, probably from northern Russia. In this icon, Christ is represented twice, behind a small altar (prestol) in the centre, shown in the act of distributing the Holy Gifts: the eucharistic bread (prosphora) to six apostles standing to the left and the wine to the six standing to the right. To the left, the Saviour is approached by Peter, Andrew, Mark, Luke, John and James; the first of them is shown in the act of receiving the eucharistic bread. Paul, Barnabas, Matthew, Bartholomew, Thomas and Simon are shown on the right; Christ is raising a small amphora with the wine to the mouth of the first of them. On the altar there is the paten (diskos), to which Christ is reaching for pieces of the eucharistic bread (which are not visible), as well as an eight-armed cross, an implement consisting of two crossed bails, which looks like an asterisk, and a wine vessel (poteiron). Schematically rendered architecture offers the background to the scene and the figures are shown in dramatic, dance-like poses; they seem to be floating in the air. The palette is dark, its prevalent colours being red, green and blue; it seems that the icon's colour range, as well as the physiognomic types, are considerably archaised. The manner of rendering the faces is very characteristic due to the shape of the heads, which are mostly seen en trois quarts, with convex foreheads and chins. On this basis, it can be assumed that the icon comes from some northern workshop. The rendering of the apostles Paul and Andrew is, however, untypical and inexplicable: they are both shown in profile, which in icon painting was effectively not performed in reference to positive characters. Inscriptions which identify the apostles are placed above them, rendered in cinnabar; above Christ, there is the Old Believer monogram IC XC in dark brown paint, and the name of the representation, "Last Supper", is found in the top field, written in red decorative Cyrillic lettering (vyaz').

Another representation that deserves attention is found in the upper part of the royal doors dated to the first half of the 18th century, originally from the house of prayer in Wojnowo, now held by the Museum of Varmia and Masuria in Olsztyn $(85 \times 95 \mathrm{~cm}$, inv. no. I 45 OMO) (Kobrzeniecka-Sikorska 1993, cat. no. 65, pp. 178-79) (Figure 2). It consists of two representations of Christ behind two altars distributing the Holy Gifts to the apostles. On the left-hand side, on the altar (prestol), there is a chalice and liturgical bread, and the first apostle in the row is Saint Peter. On the right-hand side, Christ is giving wine from a vessel to the first apostle, who is Saint Paul. The figures of Christ are surrounded with a mandorla and provided with the traditional Christological monogram IC XC. Orthodox church architecture serves as the background to both scenes. On each altar there is an eightarmed cross symbolically placed on the Golgotha, with the head of Adam at its feet and the instruments of Passion on its two sides. The two scenes are separated by a representation of the Lord of Hosts with the youthful Christ on his chest and the dove between them; thus, it is a Trinitarian image. Above the images of Christ, there are inscriptions: "Take and eat of it, all of you: this is my body, which is broken for you for the remission of sins" (on the right) and "Drink of it, all of you: this is my blood, which is shed for you and for many, for the remission of sins" (on the left). The form of the representation, the contrasting palette and the somewhat fantastic architecture bring to mind the 17th-century art of the Volga Valley. The whole object seems to refer to representations of the Communion of the Apostles placed above the royal door deriving from the 16th-century Novgorod milieu (Iz kollektsiy 1993) or from the 16th- and 17th-century products of the Stroganov and Ustyug schools of icon painting (Antonova 1966, cat. no. 58); those representations featured two figures of Christ above two altars. A similar edition of the theme functioned among the Old Believers, as demonstrated by, for instance, an icon most probably dating from the first half of the 17th century, but later submitted to restoration work in an Old Believer milieu, now held by the Museum of Russian Icons (inv. no. ČM-44). The image of Christ distributing the eucharistic bread to the apostles is there accompanied by the same text as seen on the Wojnowo icon. 


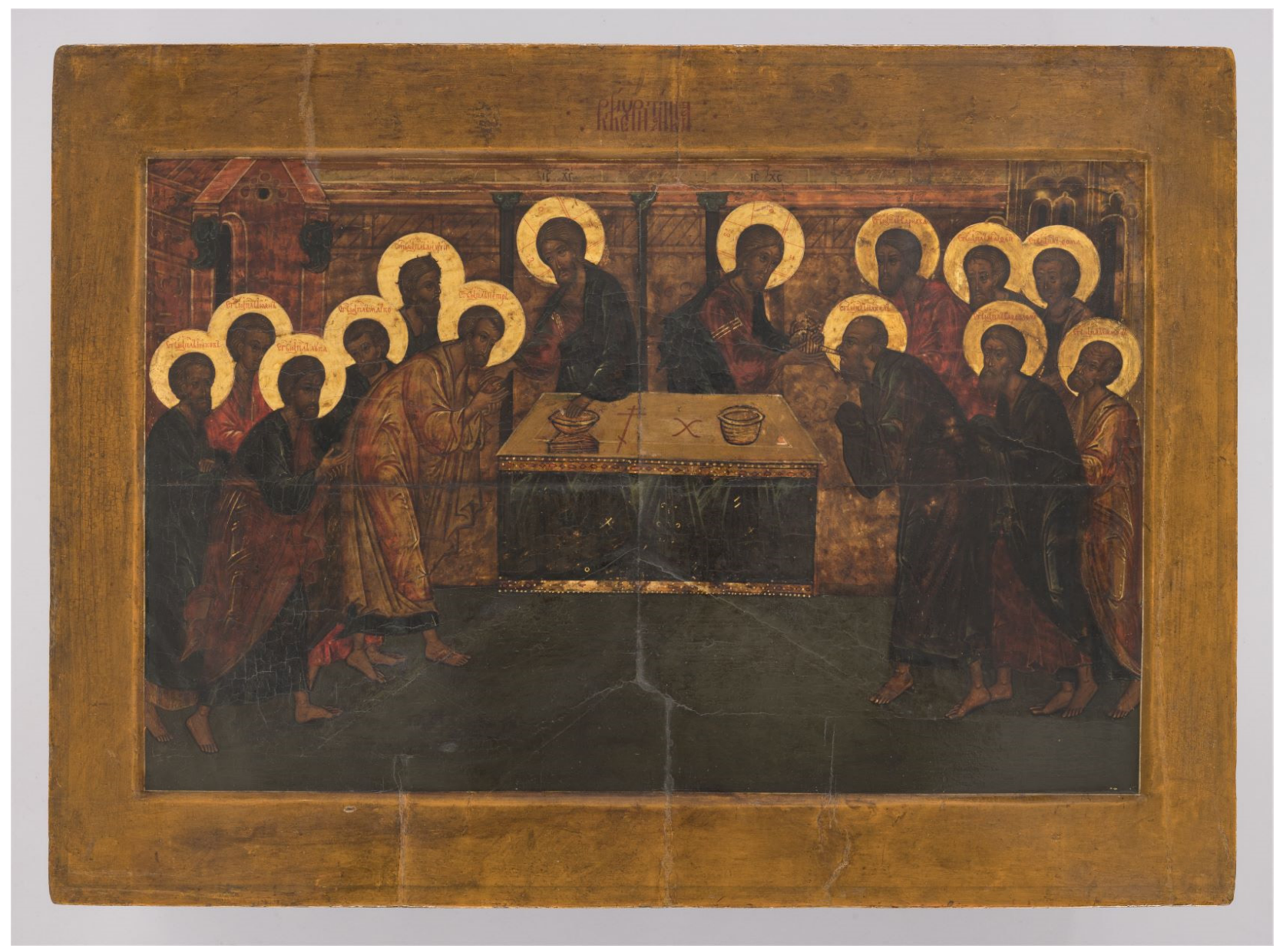

Figure 1. The Communion of Apostles, Russia, 19th c., National Museum in Warsaw.

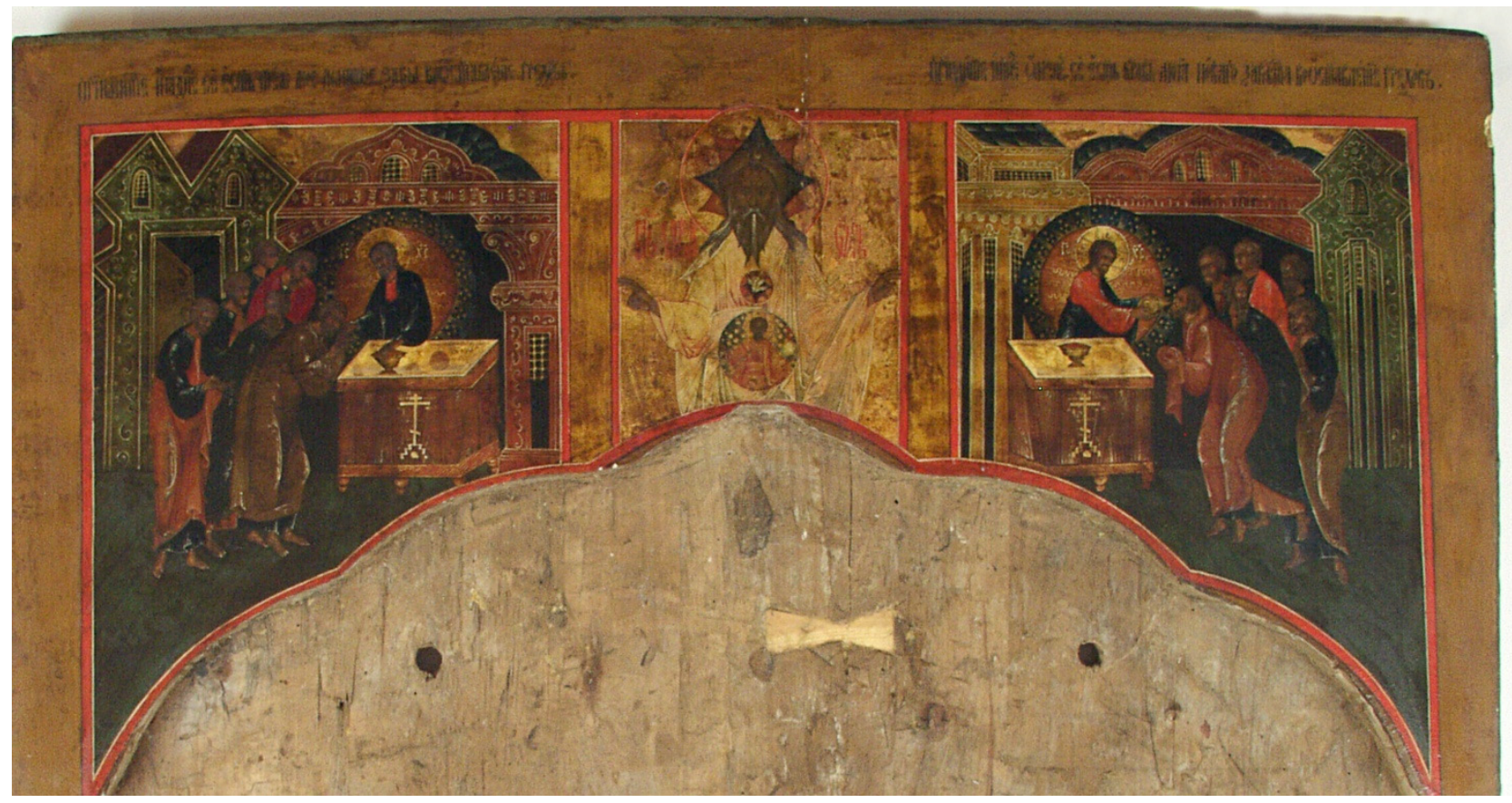

Figure 2. The upper part of the royal doors, Russia, first half of the 18th century, Museum of Varmia and Masuria in Olsztyn. 
The icon from the Olsztyn Museum is particularly important, since its provenance from the Priestless Old Believer house of prayer (molenna) in Wojnowo is well documented. This shows that representations of the Communion of the Apostles could be placed in the houses of prayer belonging to this particular group, as could the royal door of which this icon forms a part. The assumption that the icon came to the Wojnowo molenna "by accident" does not seem a good explanation of its presence there (cf. Kobrzeniecka-Sikorska 1993, p. 178), since a royal door was a relatively frequent feature of such houses of prayer (cf., e.g., the 18th-century Description of the Vygo-Leksin Hermitage in Yukhimenko 2008, p. 88). They can still be seen in active Priestless Old Believer houses of prayer; for instance, an icon of the Communion of the Apostles is found above the royal door in the iconostasis of the Pokrov molenna in Serpukhov (Figure 3) used by the Fedoseevtsy Old Believers. In its centre, similarly to the Wojnowo icon, it has a Trinitarian image, although in this case it is one of the Old Testament Trinity (cf. Image of Orthodox Church icon, mid-19th c. Pivovarova 2017, p. 10).

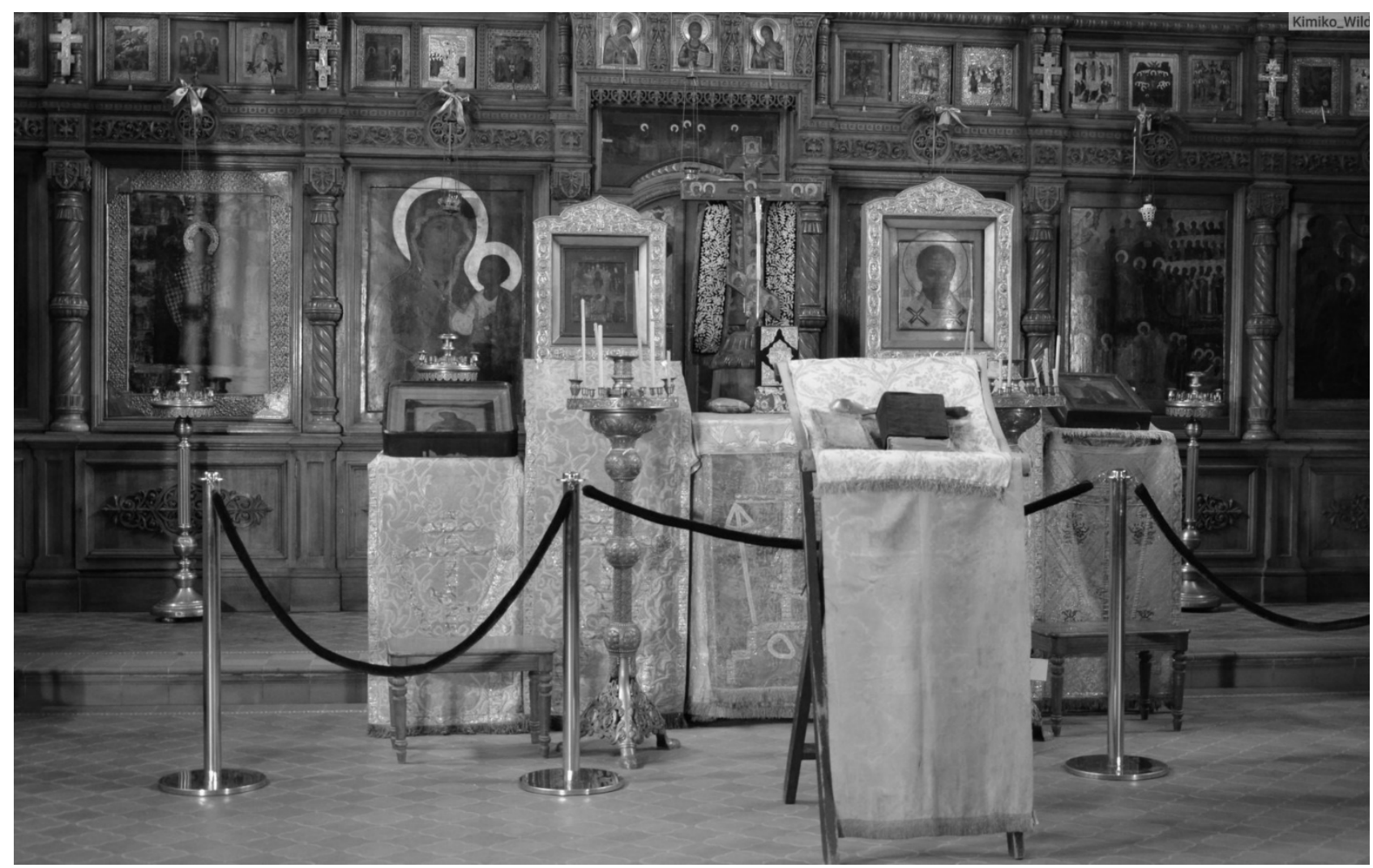

Figure 3. Interior of the Pokrov house of prayer in Serpukhov. Photo: archive of author.

The above iconography reflects the passage from the Gospel relating how the sacrament of the Eucharist was instituted during the Last Supper. However, the icons show two figures of Christ, one distributing the eucharistic bread to the apostles, the other distributing the wine. One of the participants in this act is, contrary to the biblical testimony, the apostle Paul, whereas Judas, also contrary to the Gospel text, is absent. Considering the presence of the altar, or altars, the space represented in the icon can be assumed to be sacred. The dogmatic sense of the image is parallel to the liturgical ritual, in which the distribution of the Holy Gifts each time recalls and actualises the occasion described in the Gospel. This role is described in the Liturgy of Saint Basil, in a prayer recited during the Cherubic Hymn (cherubikon), in the following way: "You [Christ] are the one who offers and who is offered, who accepts and [who] is distributed" (Walter 1982, p. 208), or, in the extended version, in the homily of Cyril of Jerusalem: "I see a child who brings to Earth a sacrifice according to the Law, but who receives in heaven the pious sacrifices of all. [I see him] on the cherubic 
throne, seated as is becoming to God. He himself is offered and purified; he himself offers and purifies all; he is the offering and he is archpriest" (Walter 1982, p. 210).

Images of the Communion of the Apostles are attested in the 6th century (Bobrik 2000, p. 526; Krueger 2014, pp. 112-13), which according to Bobrik may be associated with the emergence of the Liturgy of the Great Church in Constantinople, in which the theme of Jerusalem as the place of Christ's sacrifice played a significant role (Bobrik 2000, p. 540, cf. Taft 1980-1981). Although the oldest preserved representations are in miniature painting or in craft products, in the post-iconoclastic period they clearly dominate in mural painting as scenes intended for the sanctuaries of churches. Christopher Walter pointed to the contrast between the historical image of the Last Supper and the theological, symbolic Communion of the Apostles, which demonstrated the meaning of the liturgy (Walter 1982, p. 185; cf. Felmy 1999, pp. 259-61). It may be assumed that those representations became popular in mural painting as a result of the controversy that arose at the Synod of Constantinople in 1156, which pertained to the mystery of the Eucharist and the role played in it by Christ serving as the priest and concurrently being the sacrifice at it (Townsley 1974, pp. 138-39). According to Sharon Gerstel, the manner of its presentation-for instance, the fact that the scene did not show the wine being proffered with the help of a spoon-of the image of the Communion of the Apostles referred to the experience of clergymen, not lay believers (Gerstel 1999, pp. 56-59).

The theme of the Communion of the Apostles, frequently undertaken in mural painting, was much more rare in the iconography of Russian panel painting, where the mystic sacrifice was usually represented by the icon of the Old Testament Holy Trinity (Sulikowska 2016, pp. 123-56). It may be assumed that the earliest instances of this theme being used in Russian panel painting date from the 15th century (Bobrik 2000, p. 526). In that period, two icons with images of the apostles receiving the eucharistic bread and wine were placed in the row of festival icons (Sarab'yanov and Smirnova 2007, Figure 428). The theme is present in the programmes of Novgorod royal doors in the first half of the 15th century (Antonova and Mneva 1963, Figure 67, cat. no. 53) and in the end of the same century, as well as in the first years of the following century (Saltykov 1989, Figure 25; Novgorodskaya ikona 1983, cat. no. 133, 173, 175) and also in the icons placed above royal doors throughout the 15th and 16th centuries (Antonova and Mneva 1963, fig. 185, cat. no. 226; Iz kollektsiy 1993, cat. no. 373.); at the turn of the 16th century, this theme became popular in the Stroganov and Ustyug schools (Antonova 1966, Figure 76, cat. no. 58).

The Communion of the Apostles does not refer to the historical narrative but constitutes a metaphysical image (Felmy 1999, p. 288). It can be understood as a representation that unifies the two levels of conducting a liturgy: the terrestrial and the celestial one (Bychkov 1995, p. 200). In the context of its placement on the royal doors, according to Bobrik, its role was crucial, since, as it presented the promise of the heavenly altar, which the believers would approach in the paradisiacal reality, it was a eucharistic image that was concurrently endowed with an eschatological dimension (Bobrik 2000, pp. 533-34). It offered, as Alexander Schmemann put it, a perspective "perceptible only spiritually-a passing over into another level" (Schmemann 1988, p. 159).

The essential question is in what way the theme of the Communion of the Apostles can be referred to the idea of the Old Believer movement, especially considering that in their milieu it seems to have appeared relatively rarely. It is worth pointing out that while many communities ultimately decided to renounce liturgy, in the late 17th and early 18th century, the movement's spiritual leaders understood its importance and the dangers posed by that renunciation (Crummey 2011, pp. 123-24). For instance, in his Story of the Solovetsky Fathers and Martyrs, Semen Denisov described how, when the Solovetsky Monastery was besieged by the tsar's army, the monks who retained the "old rite" were conducting the liturgy with tears in their eyes (Yesipov 1861, p. 26). In the face of danger, Old Believers on the Vyg conducted similar, very emotional communal prayers, but they no longer conducted any communal liturgy (Smirnov 1910, p. 656), and this was the practice fervently encouraged in the adjurations of the Vyg elders (e.g., Yukhimenko 2008, II, pp. 24-25, 
28-29, 59-60). According to Robert Crummey, communal manifestations of the cult were more important in that milieu than individual piety (Crummey 2011, p. 124). It must be remembered, however, that while the Old Believers were usually forced to keep to private cult, they quite quickly reconciled themselves to the fact, as perfectly illustrated by Archpriest Avvakum's recommendation that the believers should, if necessary, conduct the liturgy individually in front of the holy icons (Zhitie protopopa Avvakuma 1979, pp. 37-38; Sulikowska-Bełczowska 2019).

This was the conduct adopted by the melchisedeks, a small splinter group of the Priestless Old Believers described by Archimandrite Paul in the late 19th century. In the evening, they would place bread and wine in front of the icons in order to receive them. After the evening and morning prayers, as the Holy Gifts, for they were thus sanctified (Pavel 1905, p. 70; Tarasov 1997, pp. 152-53). It is clear that, in this case, the icons served in place of the priests, of whom the communities were deprived, and that they mediated between the believers and God. A similar role was played by the icons among some of the netovtsy, known as the "deaf" ones (glukha netovshchina), who practiced confession before the images, during which the sins were entrusted to icons (Pavel 1905, p. 74; Smirnov 1895, p. 121; Tarasov 1997, p. 152). However, it was precisely among the melchisedeks that the icons achieved a very special status, and their presence was perceived as sanctifying and ensuring the transubstantiation of the bread and wine into the Holy Gifts. A conviction that the clergy was superfluous, and that priesthood (sometimes called "Melchizedek's priesthood") was, in a way, generally obtainable, was reportedly quite frequent in the 19th-century Old Believer milieus (Kablits 1881, pp. 70-71) and is still encountered today.

\section{The Spiritual Eucharist}

In this context, the question should be posed how exactly the Old Believers understood the liturgical image of the Communion of the Apostles, a representation that centres on the act of communion (prichastie), that is, the acceptance of the eucharistic bread and wine. Certainly, being "people of the book", they knew the Gospel and the old Orthodox literature and derived their convictions mostly from those. It is interesting to note, however, what conclusions may be drawn from the perusal of those 18th and 19th-century sources, which were the most generally known in their milieu. Two important texts of a normative nature, ones that were of key didactic value to the communities, are especially worth noting, namely the Answers of Deacon Alexander, also known as Deacon's Answers (Otvety Aleksandra Diakona/Diakonovy otvety, 1719. Otvety Aleksandra Diakona 1906), and the Pomorian Answers (Pomorskie otvety, 1723. Pomorskie otvety 1911). In this respect, as in many others, those texts focus on detailed issues rather than general ones. The Deacon's Answers points to the difference in the cross as seen on the old and new-rite eucharistic bread (Otvety Aleksandra Diakona 1906, p. 47; esp. Answer 80 and the following) and scrupulously identifies Nikonite divergences from the liturgical tradition, referring to such issues as the sanctification of the church, the correct form of the antimension (consecrated cloth) and the necessity of placing an eileton (cloth kept under the Gospel book), cross and icons on the altar (Otvety Aleksandra Diakona 1906, pp. 84-87). It is not difficult to obtain the impression that the authors of the Pomorian Answers did not attempt to deal with the general meaning of the liturgy but focused on the main points of the reforms instead: the division of the eucharistic bread into five parts instead of seven (Pomorskie otvety 1911, pp. 407-8, 412, further on: p. 427) and the sign of the cross on the eucharistic bread (Pomorskie otvety 1911, pp. 414, 429). Debated in detail in didactic literature, those issues featured also as main topics in didactic prints (Itkina 1992, pp. 57-60, cat. no. 5-6, 61, 103); they did not, however, directly impact the iconography of cult images (Figures 4 and 5).

In the answer to a question about the Eucharist as found in the Pomorian Answers, the Old Believers pointed out that Christ had said: "Who eats my flesh and drinks my blood abides in me, and I in him" (Pomorskie otvety 1911, p. 558). To the Priestless Old Believers, the sanctity of the Eucharist was obvious, but they also believed that in the times of the Antichrist it could not be conducted (cf. Zenkovskiy 1995, p. 464). In the Deacon's Answers, 
it is said that those living "in the deserts, in the mountains and in the wilds", practising chastity and keeping to the "old faith", "do not need a church, or a place, they make a church for themselves through blessed acts" (Answer 24; Otvety Aleksandra Diakona 1906, p. 208). In the context of the Eucharist, the most important passage in the Pomorian Answers is the discussion of the condition of those believers who cannot receive it (Answer 104, Pomorskie otvety 1911, p. 561). This answer describes the option of a spiritual communion available to those who have pure hearts and conduct themselves well. The true evil, it is pointed out, is not a renunciation of the Eucharist caused by external circumstances, but its acceptance without contrition and spiritual purification (Pomorskie otvety 1911, pp. 563-64).

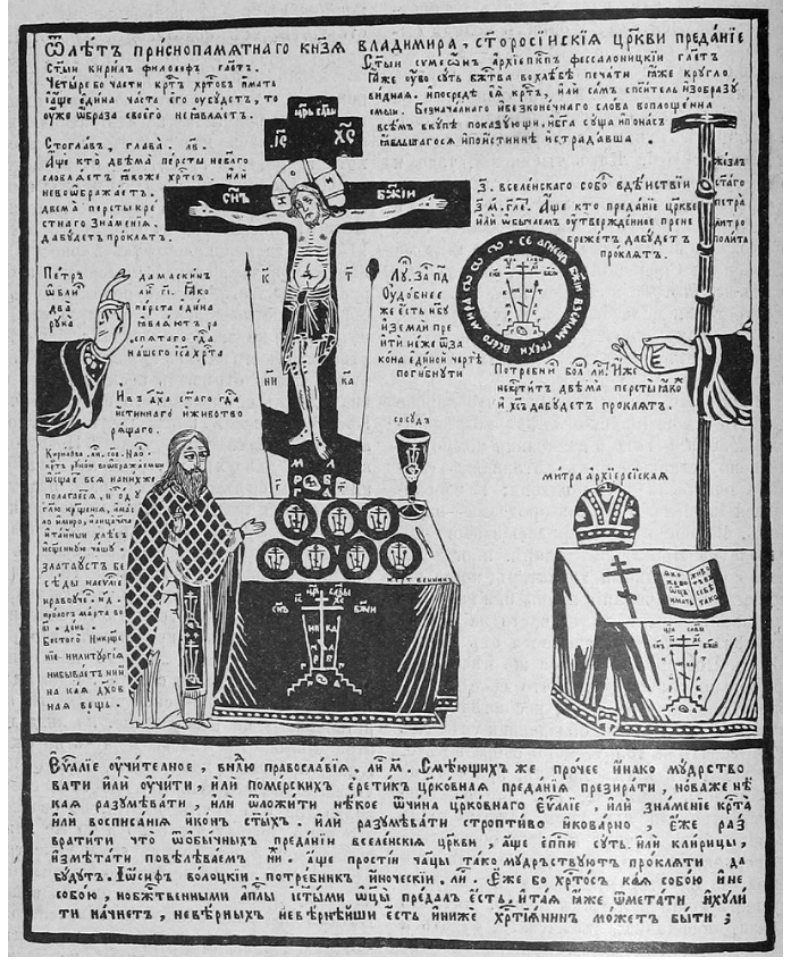

Figure 4. Old rite. Popular print of Old Believers, 19th c. Published in 'Izbornik Narodnoy gazety' (1906).

Saint Mary of Egypt, who lived alone in the desert for forty-seven years and who "owing to good deeds" spiritually "accepted Christ into herself", is given as an affirmative example of the spiritual communion. The next example is Theoktiste, who lived for thirty years on an island (Lesbos) and "did not receive communion with her mouth", but spiritually. The stances subsequently shown as commendable are those represented by Mark and Peter, two hermits of Mount Athos who lived in seclusion, "seeing no man", for fifty-three years, as well as many other hermits who "had neither a church nor a priest". Each of them "lived a life full of devotion, repented for their sins and committed good deeds" (Pomorskie otvety 1911, pp. 559-60). The Pomorian Answers refer to the authorities of Church tradition, e.g., Saint Ephrem's commendation of recluses who, living "in the mountains and in the wilds", sanctified themselves and brought salvation to the world. There is also a sizable reference to the writings of Saint Cyprian regarding the believers who attended the Lord's table spiritually. When deprived of access to the "Lord's table", persecuted believers who led a holy life "themselves became a living sacrifice" (Pomorskie otvety 1911, p. 561). In order to be worthy of the spiritual Eucharist, the Old Believers were to live in chastity, avoid sin and believe in the teachings of their community, which meant staying away from the official Orthodox Church. 


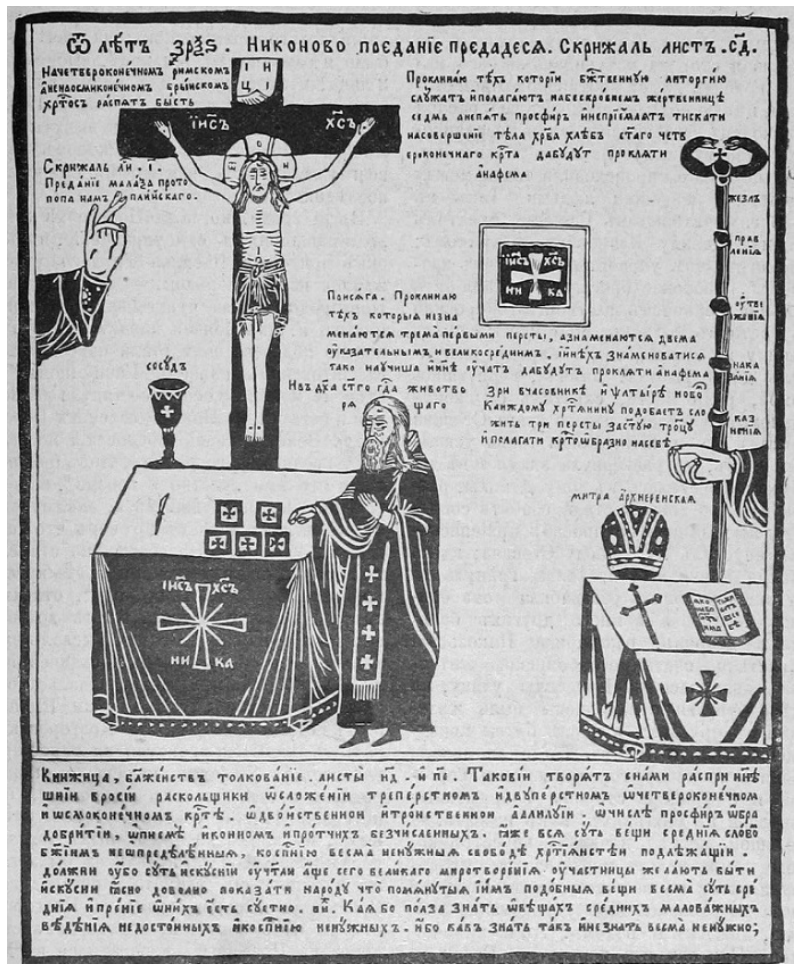

Figure 5. New rite. Popular print of Old Believers, 19th c. Published in 'Izbornik Narodnoy gazety' (1906).

Recommendations contained in the Pomorian Answers could be accepted in priestless communities and were treated there as pointing out a path for believers deprived of the chance to take the Eucharist. It is worth pointing out, however, that sources originating from the milieus of the priestly Old Believers, who retained a full liturgy with the Eucharist but for whom access to those was not at all easy owing to the distances between the communities and to the persecutions that could make it impossible for the believers to participate in ordinary practices, also describe the spiritual acceptance of the Eucharist; cases in point are Gennady and his disciple James. The latter described how his spiritual father was at night visited by angels, one bearing a paten (diskos), the other a chalice (poteiron), to give communion to the hermits-precisely because the holy elder had no other chance of receiving it (Smirnov 1898, p. 169). In the 19th century, the conviction that whoever lived according to the precepts of the Old Believer rite took the Eucharist every day became widespread in Old Believer communities (Kablits 1881, pp. 71-72). It can, therefore, be assumed that the notion of "spiritual Eucharist" taken by the believers owing to their "pure hearts" was fully accepted in the ideologies of various Old Believer groups.

In the Pomorian Answers, a large chapter devoted to the taking of the Eucharist is followed by the two final chapters of the treatise (Answers 105 and 106), which pertain to the event the Old Believers ardently awaited, namely the Last Judgement. The text closes with an expression of the conviction that at the end of times those faithful to the "old-rite" Church, together with those who had constituted it over the centuries, would "obtain communion [and] eternal joy unto the end of times" (Pomorskie otvety 1911, p. 581).

The Pomorian Answers shed new light onto the meaning that the Old Believer communities may have ascribed to the images of saints receiving spiritual communion, especially Saint Mary of Egypt, who was very popular in Old Believer icons (Chugreeva 1998, p. 393, no. 2, Figure 2; Kobrzeniecka-Sikorska 1993, cat. no. 33, 48). Representations of the Communion of the Apostles, which were exceptional and quite rare among the Old Believers, referred to a communal religious experience and not to private devotion, which was the most common Old Believer experience. Representations discussed in this article were most probably placed in the houses of prayer, on the eastern wall, in the same place where the royal door was located; in fact, those icons frequently constituted a part of the royal door. 
In this part of the house of prayer, they could have been a sui generis memento of the Liturgy of the Faithful. They may have played a role of images motivating people toward spiritual communion, which to the Old Believers was a genuine stipulation of spiritual life. However, these icons were also a token of the future communal supper in which the faithful were to join after the impending end of the world; the end of the world that the Old Believers ardently awaited and after which they expected to return to the divine altar and thus also to the liturgy and the Eucharist.

\section{Conclusions}

The Old Believers' attitude toward the liturgy and the Eucharist was shaped by their vision of the world, especially by their convictions relating to eschatology. The Old Believers refused to participate in the life and the rituals of the official Orthodox Church which, as they believed, had been taken over by the Antichrist; to most of them, the Eucharist became an experience that was not connected with ritual. Consequently, the very understanding of this sacrament by the Old Believers (especially the priestless group) underwent a fundamental change-in their circles, it came to be understood mainly in a spiritual context. This meant a radical change in religious life and unavoidably impacted religious convictions and practices, the manner of understanding icons, as well as their functioning; this was true especially in reference to icons pertaining to liturgical themes. Some images began to be imbued with new meanings, and in some cases the manner in which a representation was perceived underwent a transformation; one of those is the Communion of the Apostles.

While they declared their attachment to tradition and made it their core existential aim, the Old Believers needed to alter many of their customs, while others they began to see differently than their ancestors. Despite the absence of the eucharistic liturgy, the Old Believers nevertheless managed to retain a strong community spirit (Robson 1995, pp. 41-52) and, paradoxically, to many groups their lack of full liturgy became an element that promoted cohesion, providing an element for constructing their separate and difficult identity. An analysis of Old Believer icons not only in the context of their relation to the Old Russian past, but also through the Old Believers' own literature and their religious experience, makes it possible to perceive the distinct character of those works when seen against the backdrop of Orthodox religious art. In addition, when this perception is adopted, it becomes clear that the future research on Old Believer icons must take into consideration not only how various groups maintained the tradition and related to it, but also how, when altering their religious life, they also altered their art.

Funding: This research received no external funding.

Conflicts of Interest: The authors declare no conflict of interest.

\section{References}

Antonova, Valentina I. 1966. Drevnerusskoe iskusstvo v sobranii Pavla Korina. Moskva: Iskusstvo.

Antonova, Valentina I., and Nadezhda Ye Mneva. 1963. Katalog drevnerusskoy zhivopisi. Opyt istoriko-khudozhestvennoy klassifikatsii. Moskva: Iskusstvo.

Bobrik, Marina A. 2000. Ikona Taynoy vecheri nad tsarskimi vratami. K istorii rannykh sloev semantiki. In Ikonostas. Proiskhozhdenierazvitie — simvolika. Edited by Aleksey M. Lidov. Moskva: Progress-Traditsiya/The Ikonostasis.

Bychkov, Viktor V. 1995. Russkaya Srednevekovaya Estetika XI-XVII Veka. Moskva: Mysl'.

Chernyavskiy, Vasiliy. 1860. Ob izmeneniyakh v chine liturgiy: Ioanna Zlatousta, Vasiliya Velikogo i Grigoriya Dvoeslova, ukazannykh v Pomorskikh otvetakh i Meche dukhovnom. Kishinyov: Tipografiya Arkhiereyskogo Doma.

Chugreeva, Natal'ya. 1998. Gruppa pomorskikh ikon v sobranii Muzeya imenii Andreya Rubleva. In Mir Staroobryadchestva. Edited by Irina V. Pozdeeva. Moskva: ROSSPE, vol. IV, pp. 391-96.

Crummey, Robert O. 1970. The Old Believers and the World of Antichrist. The Vyg Community and the Russian State, 1694-1855. Madison: The University of Wisconsin Press.

Crummey, Robert O. 2011. Old Believers in a Changing World. DeKalb: Northern Illionois University Press.

DRB. 1791. Drevnyaya Rossiyskaya Vivliofika. Edited by Nikolay Novikov. Moskva: Tipografiya Kompanii Tipograficheskoy, vol. XVIII. 
Felmy, Karl Christian. 1999. "Es schweige alles menschliche Fleisch". Der Große Einzug und die "Schlachtung des Christusknaben". In "Die Weisheit baute ihr Haus". Unterschungen zu Hymnischen und Didaktischen Ikonen. Edited by Karl Christian Felmy and Eva Hausten-Bartsch. München: Deutscher Kunstverlag, pp. 251-91.

Gerstel, Sharon. 1999. Beholding the Sacred Mysteries. Programs of the Byzantine Sanctuary. Seattle-London: College Art AssociationUniversity of Washington Press.

Gorbunov, Yuriy Ye, and G. Boris Khersonskiy. 2000. Lipovanskaya ikona XVIII-XX veka. Odessa: Druk.

Grebenyuk, Tat'yana Ye. 2004. Vetkovskaya ikona. In Staroobryadchestvo v Rossii (XVII-XX veka). Moskva: Yaziki slavyanskoy kul'tury, pp. 274-90.

Itkina, Yelena I. 1992. Russkiy Risovannyy Lubok Kontsa XVIII—Nachala XX veka: Iz Sobraniya Gosudarstvennogo Istoricheskogo Muzeya. Moskva: Russkaya Kniga.

Iz kollektsiy. 1993. Iz kollektsiy akademika N. P. Likhacheva. Katalog vystavki. Sankt-Peterburg: Izdatel'stvo "Seda-C".

Kablits, Iosif I. 1881. Kablits Iosif I. (I. Yuzov) Russkie dissidenty. Starovery i Dukhovnye Khristiane. S.-Peterburg: Tipografiya A. M. Kotomina.

Karpenko, Yelena. 2006. “Obraz litoy starinnyy ... ". Mednoe Khudozhestvennoe lit'e XII-XX vv. iz Sobraniya Natsional'nogo khudozhestvennogo muzeya Respubliki Belarus'. Minsk: Belprint.

Kobrzeniecka-Sikorska, Grażyna. 1993. Ikony Staroobrzędowców w Zbiorach Muzeum Warmii i Mazur w Olsztynie. Olsztyn: Muzeum Warmii i Mazur.

Kozhurin, Kirill. 2014. Povsednaya Zhizn' Staroobryadtsev. Moskva: Molodaya Gvardiya.

Krueger, Derek. 2014. Liturgical Subject. Christian Ritual, Biblical Narrative, and the Formation of the Self in Byzantium. Philadelphia: University of Pensylvania Press.

Lobachev, Sergey V. 2003. Patriarkh Nikon. Sankt-Peterburg: Iskusstvo-SPb.

Mal'tsev, Aleksandr I. 2006. Staroobryadcheskie Bespopovskie Soglasiya v XVIII-Nachale XIX v. Problema Vzaimootnosheniy. Novosibirsk: ID "Sova".

Meyendorff, Paul. 1991. Russia, Ritual, and Reform: The Liturgical Reforms of Nikon in the 17th Century. Crestwood: St Vladimir's Seminary Press.

Nechaeva, Galina G. 2002. Vetkovskaya Ikona. Minsk: Izdatel'stvo “Chetyre chetverti”.

Nev'yanskaya ikona. 1997. Nev'yanskaya Ikona. Yekaterinburg: Izdatel'stvo Ural'skogo universiteta.

Novgorodskaya ikona. 1983. Novgorodskaya Ikona XII-XVII vekov. Leningrad: Izdatel'stvo "Avrora".

Otvety Aleksandra Diakona. 1906. (na Kerzhentse) podannyya Nizhegorodskomuepiskopu Pitirimu v" 1819 [a mistake in the title; it should be: 1719] godu. Besplatnoe prilozhenie k zhurnalu "Staroobryadets". Nizhniy Novgorod: Tovarishchestvo Tipo-Litografiya I. M. Mashistova.

Paaver, Mari-Liis, and Grigoriy Potashenko. 2016. Ikonopisets v XX veke. Zhizn' i tvorchestvo Ivana Ipat'evicha Mikhaylova. Vil'nyus: Izdatel'stvo Vil'nyusskogo universiteta.

Pavel, Arkhimandryt. 1905. Kratkiya izvestiya o sushchestvuyushchikh" v Raskole sektakh. Moskva: Tipografiya E. Lissnera i D. Sovko.

Pivovarova, Nadezhda V. 2004. Ob odnom epizode iz istorii "bor'by s raskolom" v seredine XIX v.: Sudislavskie molennye N. A. Papulina i ikh sud'ba po dokumentam Rossiyskogo Gosudarstvennogo Istoricheskogo Arkhiva. In Staroobryadchestvo v Rossii (XVII-XX veka). Vol. III, Edited by Ye. M. Yukhimenko. Moskva: Yaziki slavyanskoy kul'tury, pp. 358-84.

Pivovarova, Nadezhda V. 2017. Staroobryadcheskaya Ikona v istoriko-kul'turnom Kontekste XVIII-Nachale XX veka: Opyt Sistematicheskogo Analiza. Moskva: BuksMART.

Pomorskie otvety. 1911. Pomorskie Otvety. Napechatany s" Podlinnika. Moskva: Tipografiya P. P. Rabushinskago.

Potashenko, Grigoriy. 2017. Vil'nyusskaya shkola staroobryadcheskoy ikonopisi: Ivan Mikhaylov i yego ucheniki. Slavistica Vilnensis 62: $321-48$.

Robson, Roy R. 1995. Old Believers in Modern Russia. DeKalb: Northern Illinois University Press.

Saltykov, Aleksandr. 1989. Muzey Drevnerusskogo Iskusstva Imenii Andreya Rubleva. Leningrad: Khudozhnik RSFSR.

Sarab'yanov, Vladimir B., and Engelina S. Smirnova. 2007. Istoriya Drevnerusskoy Zhivopisi. Moskva: Izdatel'stvo Svyato-Tikhonovskogo gumanitarnogo universiteta.

Sazonova, Nataliya I. 2008. U istokov raskola Russkoy Tserkvi v XVII veke: Ispravlenie bogosluzhebnykh knig pri patriarkhe Nikone (1654-1666 gg.) (na materialakh Trebnika i Chasoslova). Tomsk: Izd-vo TGPU.

Schmemann, Alexander. 1988. Eucharist-Sacrament of the kingdom. Crestwood: St. Vladimir's seminary.

Smirnov, Pyotr S. 1895. Istoriya Russkago raskola starooobryadchestva. S.-Peterburg: Tipografiya Glavnago Upravleniya Udelov.

Smirnov, Pyotr S. 1898. Vnutrennie voprosy v" raskole v" XVII veke. S.-Peterburg: Tovarishchestvo "Pechatnya S. P. Yakovleva".

Smirnov, Pyotr S. 1909. Spory i razdeleniya v russkom raskole v pervoy chetverti XVIII veka. S.-Peterburg: Tipografiya M. Merkusheva.

Smirnov, Pyotr S. 1910. Vygovskaya bezpopovshchinskaya pustyn' v pervoe vremya yeyo sushchestvovaniya: Osobennosti ucheniya i vazhneyshie sobytiya. Khristianskoe Chtenie № 5-6: 638-74.

Subbotin, Nikolay. 1878. Materialy dlya istorii raskola za pervoe vremya yego sushchestvovaniya. Moskva: Tipografiya T. Ris, vol. III.

Subbotin, Nikolay. 1881. Materialy dlya istorii raskola za pervoe vremya yego sushchestvovaniya. Moskva: Tipografiya E. Lissner i Yu. Roman, vol. VI.

Sulikowska, Aleksandra. 2013. Icons of John the Baptis in the Collection of the National Museum in Warsaw: The Angel's Body, a Martyr's Death, Holy Remains. Journal of the National Museum in Warsaw 2: 203-16. 
Sulikowska, Aleksandra. 2016. The Icon Debate. Religous Images in Russia in the 15th and 16th Centuries. Frankfurt am Main: Peter Lang. Sulikowska-Bełczowska, Aleksandra. 2019. The Cult of Old Believers' Domestic Icons and the Beginning of Old Belief in the 17th-18th Centuries. Religions 10: 574. [CrossRef]

Taft, Robert. 1980-1981. The Liturgy of the Great Church: An Initial Synthesis of Structure and Interpretation on the Eve of Iconoclasm. Dumbarton Oaks Papers 34/35: 45-75.

Tarasov, Oleg. 1997. Staroobryadcheskoe ikonopochitanie i tema Antikhrista. In Kul'tura i istoriya. Slavyanskiy mir. Moskva: Izdatel'stvo "Indrik", pp. 140-58.

Tarasov, Oleg. 2002. Icon and Devotion. Sacred Spaces in Imperial Russia. Translated and Edited by Robin Milner-Gulland. London: Reaktion Books.

Townsley, Ashton L. 1974. Eucharistic Doctrine and the Liturgy In Late Byzantine Period. Oriens Christianus 58: 146-53.

Walter, Christopher. 1982. Art and Ritual of the Byzantine Church. Preface by Robin Cormack. London: Variorum Publications LTD.

White, James M. 2020. Unity in Faith? Edinoverie, Russian Orthodoxy, and Old Belief, 1800-1918. Bloomington: Indiana University Press.

Yesipov, Grigoriy. 1861. Raskol'nich'i dela XVIII stoletiya. Materialy i prilozheniya. SanktPeterburg: Tipografiya Tovarishchestva “Obshchestvennaya Pol'za".

Yukhimenko, Yelena M. 2008. Literaturnoe nasledie Vygovskogo staroobryadcheskogo obshchezhitel'stva, I-II. Moskva: Yaziki slavyanskoy kul'tury.

Zenkovskiy, Sergey A. 1995. Russkoe staroobryadchestvo. Dukhovnye dvizheniya semnadtsatogo veka. Moskva: Tserkov.

Zhitie protopopa Avvakuma. 1979. Zhitie protopopa Avvakuma im samim napisannoe i drugie yego sochinieniya. Irkutsk: Vostochno-Sibirskoe knizhnoe izdatel'stvo. 